\title{
Metronomic treatment of temozolomide inhibits tumor cell growth through reduction of angiogenesis and augmentation of apoptosis in orthotopic models of gliomas
}

\author{
JI TAE KIM ${ }^{1,2 *}$, JONG-SOO KIM ${ }^{1 *}$, KWANG WON KO ${ }^{*}$, DOO-SIK KONG ${ }^{1}$, CHANG-MO KANG $^{2}$, \\ MI HYUN KIM ${ }^{1}$, MYUNG JIN SON ${ }^{1}$, HYUN SEOK SONG ${ }^{1}$, HYUNG-JIN SHIN ${ }^{1}$, \\ DONG-SUP LEE ${ }^{3}$, WHAN EOH ${ }^{1}$ and DO-HYUN NAM ${ }^{1,4}$ \\ ${ }^{1}$ Department of Neurosurgery, Samsung Medical Center and Samsung Biomedical Research Institute, \\ Sungkyunkwan University School of Medicine; ${ }^{2}$ Laboratory of Radiation Cytogenetics and Epidemiology, \\ Korea Institute of Radiological and Medical Sciences; ${ }^{3}$ Cancer Research Institute, Seoul National \\ University College of Medicine; ${ }^{4}$ Xenotransplantation Research Center, Seoul, Korea
}

Received January 23, 2006; Accepted March 13, 2006

\begin{abstract}
Glioblastoma is a highly angiogenic tumor with a dismal prognosis. Temozolomide (TMZ), a methylating agent is one of the most effective chemotherapeutic agents against glioblastoma. To overcome the problem that most of these tumors become resistant to chemotherapeutic regimens within a year, we investigated the antitumor efficacy of metronomic administration of low-dose TMZ in in vitro cell proliferation/ cytotoxicity assay and in vivo rat and nude mouse orthotopic glioma model. By in vitro assay, we elucidated that C6/LacZ rat glioma cells were more resistant to metronomic treatment of TMZ than U-87MG human glioblastoma cells and bEnd.3 mouse brain endothelial cells. Compared with the conventional chemotherapeutic regimen of TMZ, we found that frequent administration of TMZ at a low dose (metronomic treatment) markedly inhibited angiogenesis as well as tumor growth in a TMZ-resistant C6/LacZ rat glioma model. In addition, metronomic treatment of TMZ significantly augmented apoptosis of tumor cells in this model. For the TMZ-sensitive U-87MG cells, even with a very low dose of TMZ, which is not effective
\end{abstract}

Correspondence to: Dr Do-Hyun Nam, Department of Neurosurgery, Samsung Medical Center and Samsung Biomedical Research Institute, Sungkyunkwan University School of Medicine, 50 Irwondong, Gangnam-gu, Seoul 135-710, Korea

E-mail: nsnam@smc.samsung.co.kr

${ }^{*}$ Contributed equally

Abbreviations: TMZ, temozolomide; MVD, microvessel density; TUNEL, terminal deoxynucleotidyl-mediated deoxyuridine triphosphate nick-end labeling

Key words: glioma, temozolomide, metronomic chemotherapy, orthotopic model to reduce tumor mass, the metronomic treatment of $\mathrm{TMZ}$ reduced the microvessel density, i.e. angiogenesis, in a nude mouse orthotopic model. In conclusion, for both models, the metronomic treatment of TMZ decreased angiogenesis. Especially, in TMZ-resistant glioma cells, this regimen increased apoptosis of tumor cells and decreased tumor growth. The metronomic treatment of TMZ in orthotopic glioma models demonstrated a successful antiangiogenic effect which can overcome the chemoresistance in conventional TMZ chemotherapy.

\section{Introduction}

Malignant gliomas are the most common subtypes of rapidly growing primary brain tumors in adults and the most angiogenic human tumors which are characterized by a remarkable proliferative vascular component (1). They have retained their poor prognosis despite aggressive diverse conventional therapeutic approaches, requiring us to find novel therapeutic strategies (2). Particularly, for management of the growth of tumors including gliomas, which are dependent on angiogenesis, i.e. proliferation of microvascular endothelial cells, vascular targeted therapy has been the focus of recent studies.

Temozolomide (TMZ) exhibits broad-spectrum antitumor activity on diverse tumors such as human melanoma, ovarian, colon and brain tumors (3-5). It is a DNA alkylating agent and an imidazotetrazine derivative used in the therapy of malignant gliomas $(6,7)$. Since it has lipophilic property, TMZ is orally available and has shown excellent tissue distribution, including penetration across the blood-brain barrier (3). Although TMZ possesses good antitumor activity, its application in the management of high-grade glioma is limited by various resistant mechanisms (8), which leads many studies to explore the optimization of antitumor efficacy through combination of TMZ with radiation therapy or another agent $(6,9-11)$. It was also reported that the antitumor activity of TMZ is found to be highly schedule-dependent, with multiple administrations being more effective than a single bolus dose (12). 
Recently, many experimental and preclinical studies have suggested that frequent administration in vivo of low doses of chemotherapeutic drugs could affect tumor endothelium and inhibit tumor angiogenesis, reducing significant side effects (13-15). These frequent administrations of certain agents with low doses, known as metronomic chemotherapy, especially increase the antiangiogenic activity $(16,17)$.

In this study, we elucidate the antitumor, antiangiogenic and pro-apoptotic activity of metronomic treatment with TMZ through in vitro cell proliferation/cytotoxicity assay and in vivo orthotopic rat and mouse models of gliomas.

\section{Materials and methods}

Cell culture. The rat glioma cell line, C6/LacZ, and bEnd.3 mouse cerebral cortex endothelial cells (ATCC, Manassas, VA) were cultured in Dulbecco's modified essential medium supplemented with $10 \%$ fetal bovine serum (FBS), penicillin (100 units $/ \mathrm{ml})$, and streptomycin $(100 \mu \mathrm{g} / \mathrm{ml})$, and U-87MG human glioblastoma cells (ATCC) were grown in Eagle's minimal essential medium supplemented with $10 \%$ FBS, 2 mM L-glutamine, non-essential amino acids, sodium pyruvate, penicillin (100 units/ml), and streptomycin $(100 \mu \mathrm{g} / \mathrm{ml})$. These cells were maintained at $37^{\circ} \mathrm{C}$ in an incubator flushed continuously with $5 \% \mathrm{CO}_{2}$.

In vitro cell proliferation/cytotoxicity assay. Temozolomide (TMZ, temodal) was generously provided by Yuhan Corp. (Seoul, Korea) and dissolved in 10\% DMSO. To determine the effectiveness of metronomic TMZ treatment in glioma, we evaluated the effects of various concentrations of TMZ on the proliferation of $\mathrm{C} 6 / \mathrm{LacZ}$ and $\mathrm{U}-87 \mathrm{MG}$ cells using Cell Counting Kit-8 (CCK-8, Dojindo Laboratories, Kumamoto, Japan) which is a sensitive non-radioactive colorimetric assay kit for determining the number of viable cells in cell proliferation and cytotoxicity assays. To evaluate the efficacy of metronomic treatment for the glioma associated vascular endothelial cells, we used bEnd.3 which has characteristics of brain endothelial cells (18). After plating these cells into 96-well plates, each TMZ concentration was represented by 5 wells and replicated three times, similar to a previous report which studied the drug effects of prolonged continuous exposures on various cells (15). The cells were treated with TMZ (1-100 $\mu \mathrm{M})$ for $144 \mathrm{~h}\left(1-3 \times 10^{3}\right.$ cells/well in $100 \mu \mathrm{l}$ of medium). To keep the TMZ concentration constant during the 144-h experiment periods, the medium and the drug were freshly replaced every day.

Animals and orthotopic implantation of tumor cells. For orthotopic glioma model, male Sprague-Dawley (SD) rats (200-250 g) and male Balb/c-nu mice (6 weeks) were housed and maintained under specific pathogen-free conditions in facilities approved by the Association for Assessment and Accreditation of Laboratory Animal Care International and in accordance with the current regulations and standards of the Laboratory Animal Research Center under Samsung Biomedical Research Institute. SD rats and Balb/c-nu mice were anesthetized with intraperitoneal injection of $75 \mathrm{mg} / \mathrm{kg}$ ketamin and $5 \mathrm{mg} / \mathrm{kg}$ xylazine, and $100 \mathrm{mg} / \mathrm{kg} \mathrm{ketamin}$ and $10 \mathrm{mg} / \mathrm{kg}$ xylazine, respectively. The heads of the anesthetized animals were shaved and disinfected with a solution of $70 \%$ ethanol and povidone iodine, after which they were secured in a rodent stereotatic frame. A midline incision was made on the dorsal aspect of the head and the pericranium was laterally to expose the bregma. The screw was implanted into a small drill hole made $3 \mathrm{~mm}$ (SD rats) or $2 \mathrm{~mm}$ (Balb/c-nu mice) left lateral and $1 \mathrm{~mm}$ anterior to the bregma (19). The cells were harvested from subconfluent cultures by brief exposure to $0.25 \%$ trypsin and $0.02 \%$ EDTA. Only single cell suspensions with $95 \%$ viability were used for the in vivo implantation. To produce tumors, C6/LacZ and U-87MG tumor cells ( $1 \times 10^{5}$ cells $/ 10 \mu 1$ of Hanks balanced salt solution) were injected into the white matter at a depth of $5 \mathrm{~mm}$ for SD rats or $2 \mathrm{~mm}$ for Balb/c-nu mice, respectively, through a $10-\mu 1$ Hamilton syringe connected to the manipulating arm of the produced 7-stereotatic device. All injections consisted of a total volume of $10 \mu \mathrm{l}$ delivered over $12.5 \mathrm{~min}$ by a microinfusion pump.

Drug administration. Before treatment of TMZ, the rats were randomized into four groups ( $\mathrm{n}=10$ per group). One experimental group of rats was administered orally with $7 \mathrm{mg} / \mathrm{kg}$ TMZ for 5 days (between day 7 and 11 after intracranial implantation). Two groups of rats were respectively administered 1 or $2 \mathrm{mg} / \mathrm{kg}$ TMZ via per os (p.o.) everyday for 16 days. The control group was treated by injection via p.o. with $10 \%$ DMSO. Human U-87MG at nude mice brain is so sensitive to TMZ that we minimized the TMZ dose which starts to show antitumor activity. Then the mice were randomized into five groups ( $\mathrm{n}=15$ per group): two conventionally-treated groups were administered orally with 2.5 or $1.25 \mathrm{mg} / \mathrm{kg}$ TMZ for 5 days, respectively (between day 14 and 18 after intracranial implantation); two groups were treated orally with each dose of TMZ (0.5 and $0.25 \mathrm{mg} / \mathrm{kg})$ daily for 25 days; and control mice were treated by p.o. with $10 \%$ DMSO.

Harvesting of specimens. Seventeen and twenty five days after the inoculation of tumor cells, rats and mice were anesthetized and sacrificed respectively. And then, the brains of these animals were removed and sectioned axially. One section was fixed in $10 \%$ buffered formalin and embedded in paraffin, and the other was embedded in OCT compound, frozen rapidly in liquid nitrogen, and stored at $-70^{\circ} \mathrm{C}$. The tumor volume was calculated by measuring the section with the largest tumor portion and applying the formula: Length $\mathrm{x} \mathrm{Width}^{2} \mathrm{x} 0.5$ (20).

Immunohistochemistry and quantification of immunostaining. Immunohistochemistry was performed as described previously (20). The microvessel density (MVD) was determined by immunohistological staining using antibody for rat anti-mouse CD31/PECAM-1 (BD Pharmingen, San Diego, CA) in both glioma models. For the quantification of immunostaining for CD31, the number of stained cells was counted in ten random fields at x200 magnification. The apoptotic glioma cells were visualized by a commercially available terminal deoxynucleotidyl-mediated deoxyuridine triphosphate nick-end labeling (TUNEL) kit (Intergen Co., Purchase, NY) in C6/LacZ rat glioma orthotopic model. For TUNEL assay, the number of stained cells was counted in ten random fields at $\mathrm{x} 400$ magnification. 


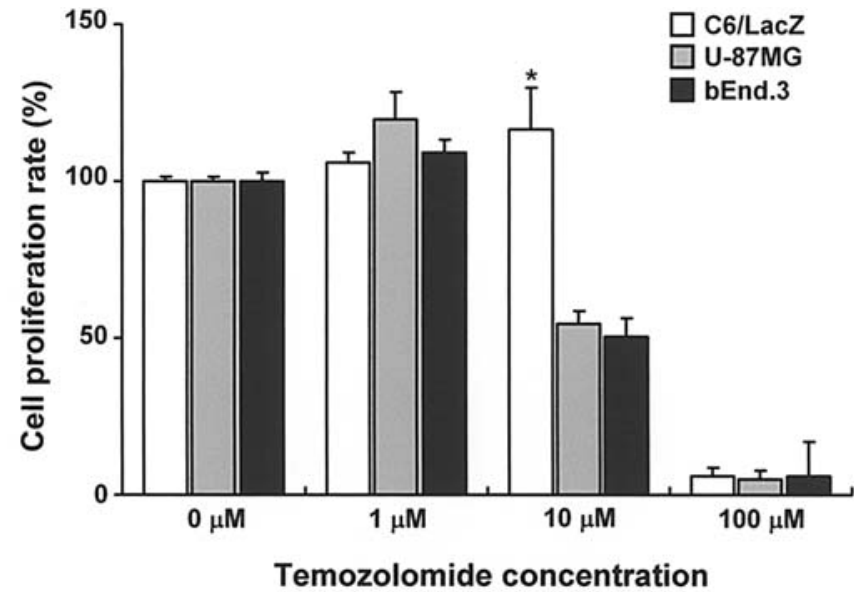

Figure 1. The effects of various doses of TMZ on cell proliferation and cytotoxicity in C6/LacZ, U-87MG and bEnd. 3 cells. The proliferation rates of each cell on respective dose of TMZ for $144 \mathrm{~h}$ were checked by CCK-8 which is a sensitive colorimetric assay kit for determining the number of viable cells. Each value represents the mean \pm SD. ${ }^{*}$ Higher than in U-87MG and bEnd.3 cells treated with $10 \mu \mathrm{M}$ TMZ $(\mathrm{P}<0.01)$

Data analysis and statistics. Values are presented as means \pm $\mathrm{SE}$ or $\pm \mathrm{SD}$ from $\mathrm{n}$ animals. Statistical comparisons between groups were performed using Student's t-test or ANOVA. Values of $\mathrm{P}<0.05$ were considered statistically significant.

\section{Results}

C6/LacZ cells are more resistant to metronomic treatment with TMZ than U-87MG and bEnd.3 cells on cell proliferation. For determination of the effectiveness of metronomic treatment with TMZ in glioma and glioma associated vascular endothelial cells, we evaluated the effects of various concentrations of TMZ on cell proliferation of two glioma cells and bEnd.3 cells using CCK-8 (Dojindo Laboratories). Significant inhibition of cell proliferation was observed in $\mathrm{C} 6 / \mathrm{LacZ}$, U-87MG and bEnd. 3 cells treated with $100 \mu \mathrm{M}$ of TMZ for 144 h, respectively (Fig. 1). In contrast, the proliferation rate of $\mathrm{C} 6 / \mathrm{LacZ}$ cells $(\mathrm{P}<0.01)$ was not changed in the treatment group of $10 \mu \mathrm{M}$ TMZ compared with those of other groups of cells (Fig. 1). In detail, the value of $\mathrm{IC}_{50}$ for $\mathrm{C} 6 / \mathrm{LacZ}$ cells (104.14) was shown to approximately 10.6-fold augmentation compared with those for U-87MG (9.85) and bEnd.3 (9.72) cells, which suggested that $\mathrm{C} 6 / \mathrm{LacZ}$ cells were more resistant to TMZ than U-87MG and bEnd.3 cells. According to the in vitro data, C6 glioma cells of rat brain seem to be resistant to TMZ chemotherapy, whereas tumor associated proliferating endothelial cells seem to be sensitive to antiangiogenic TMZ chemotherapy.

Metronomic treatment with TMZ inhibits tumor growth in C6/LacZ rat glioma orthotopic model. To find the optimal dose effect of TMZ in an animal model, we orally administered the same dose of TMZ $(7 \mathrm{mg} / \mathrm{kg}$ ) or $10 \%$ DMSO (control) for 5 days to rats and mice after intracranial implantation of $\mathrm{C6} / \mathrm{LacZ}$ and $\mathrm{U}-87 \mathrm{MG}$ cells respectively.

Compared with control (median volume, $74.4 \mathrm{~mm}^{3}$ ), the tumor volume in rats treated with conventional TMZ chemotherapy was slightly reduced (median volume, $52.4 \mathrm{~mm}^{3}$ ) on the 16th day after the inoculation of tumor cells (Table I), while tumor formation in mice was completely blocked on the 25th day after the inoculation of tumor cells (data not shown), which means that tumor was not grown in $7 \mathrm{mg} / \mathrm{kg}$ TMZ-treated mice. Therefore, C6 glioma in rat brain was relatively resistant to the TMZ chemotherapy in accordance with the results of the cell proliferation experiment (Fig. 1).

In both a rat and mouse animal model, there were no signs of toxicity of drug administration, such as body weight loss, in either group (data not shown).

To determine the antitumor activity of TMZ on gliomas, we measured the tumor volume after each treatment of TMZ in a C6/LacZ rat glioma orthotopic model (Table I, Fig. 2A). Control rats had the largest brain tumors (median volume, $74.4 \mathrm{~mm}^{3}$ ). In contrast, all groups treated with TMZ had reduced brain tumor volumes. The tumor masses of rats administered $7 \mathrm{mg} / \mathrm{kg}$ TMZ for 5 days were reduced by $30 \%$ compared to those of controls (median volume, $52.4 \mathrm{~mm}^{3}$ ), whereas the tumor masses of rats which were administered daily with $2 \mathrm{mg} / \mathrm{kg}$ TMZ were markedly reduced by $70 \%$

Table I. Tumor volume, microvessel density (MVD) and apoptosis index in a C6/LacZ rat glioma model.

\begin{tabular}{|c|c|c|c|c|c|c|}
\hline \multirow{2}{*}{$\begin{array}{l}\text { Treatment } \\
\text { group }\end{array}$} & \multicolumn{2}{|c|}{ Tumor volume $\left(\mathrm{mm}^{3}\right)$} & \multicolumn{2}{|c|}{ MVD (no.) } & \multicolumn{2}{|c|}{ TUNEL (no.) } \\
\hline & Median & Range & Median & Range & Median & Range \\
\hline Control & 74.4 & $1.5-292.9$ & 23 & $16-35$ & 2 & $1-3$ \\
\hline $7 \mathrm{mg} / \mathrm{kg}$ TMZ for 5 days & 52.4 & $19.6-255.6$ & 19 & $10-30$ & $5^{c}$ & $2-13$ \\
\hline 2 mg/kg TMZ daily & $22.3^{\mathrm{a}}$ & $1.3-79.5$ & $12^{\mathrm{b}}$ & $7-24$ & $14^{\mathrm{d}}$ & $6-23$ \\
\hline $1 \mathrm{mg} / \mathrm{kg} \mathrm{TMZ}$ daily & 49.7 & $0.0-186.5$ & 22 & $15-33$ & 2 & $0-5$ \\
\hline
\end{tabular}

C6/LacZ rat glioma cells $\left(1 \times 10^{5}\right)$ were injected into the male Sprague-Dawley (SD) rat brain. The respective groups of rats were treated by p.o. injection with $7 \mathrm{mg} / \mathrm{kg}$ temozolomide (TMZ) for 5 days or oral administration with 1 or $2 \mathrm{mg} / \mathrm{kg}$ TMZ daily. Control group of rats was

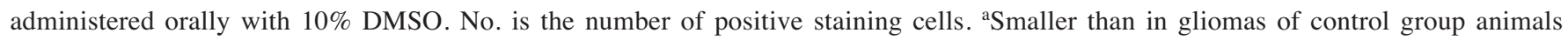
$(\mathrm{P}<0.05)$. ${ }^{b}$ Lower than in gliomas of control animals $(\mathrm{P}<0.001)$. ${ }^{\mathrm{c}}$ Higher than in gliomas of control group animals $(\mathrm{P}<0.001)$. ${ }^{\mathrm{d}}$ Higher than in gliomas of the other groups of animals $(\mathrm{P}<0.05)$. 
A

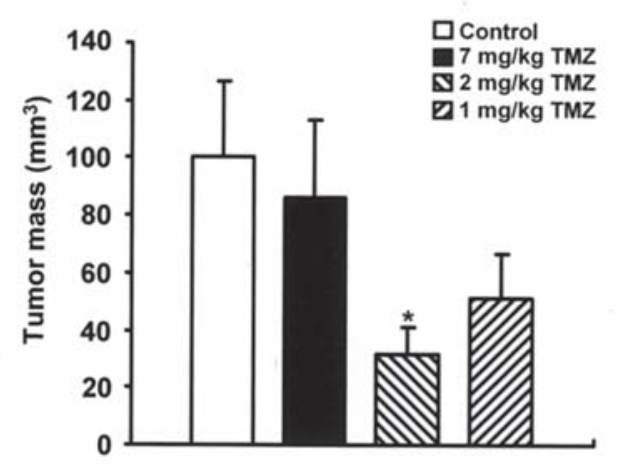

B

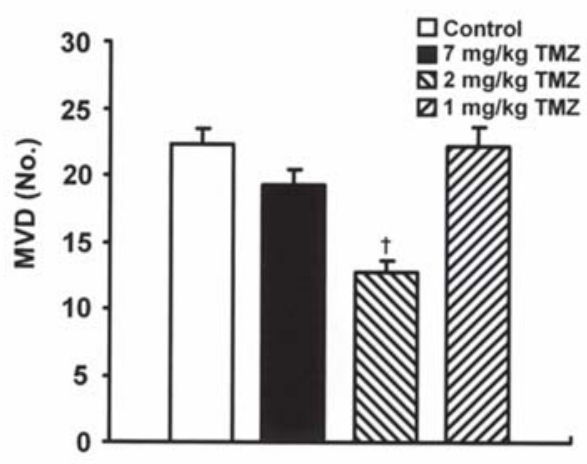

\section{C}

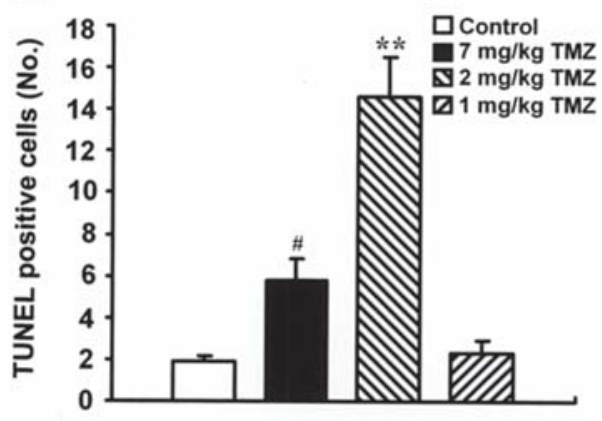

D

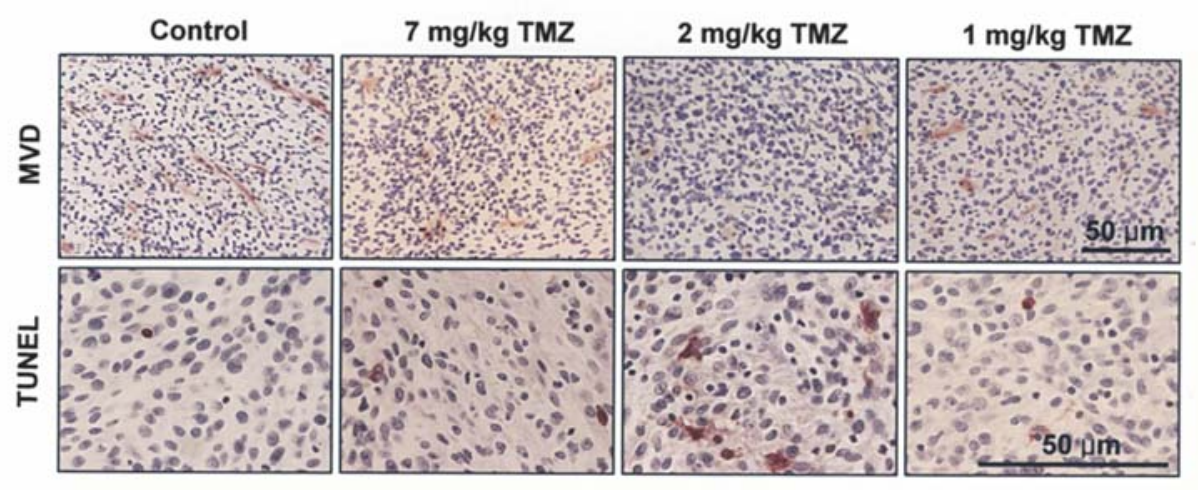

Figure 2. The effects of TMZ on C6/LacZ rat gliomas in orthotopic model. Tumor volume (A), microvessel density (MVD, B) and TUNEL positive cells (C) are graphed respectively. Each value represents the mean $\pm \mathrm{SE}(\mathrm{n}=10)$. The values of mean in this figure are different from those of the median in Table $\mathrm{I}$. ${ }^{*}$ Smaller than in gliomas of control group animals $(\mathrm{P}<0.05)$. ${ }^{\dagger}$ Lower than in gliomas of control $(\mathrm{P}<0.001)$. "Higher than in gliomas of control $(\mathrm{P}<0.001)$. ${ }^{* *}$ Higher than in gliomas of the other group animals $(\mathrm{P}<0.05)$. (D) Paraffin sections of the tumors were stained for endothelial cells using anti-CD31 antibody (upper pannels) and apoptotic cells using TUNEL assay (lower pannels), respectively.

compared with those of controls (median volume, $22.3 \mathrm{~mm}^{3}$, $\mathrm{P}<0.05)$. Furthermore, the reduction of tumor mass was also observed, even with half the amount of the total dose used for conventional TMZ chemotherapy (median volume, $49.7 \mathrm{~mm}^{3}$ ).

Metronomic treatment with TMZ inhibited angiogenesis and induced apoptosis in an orthotopic rat glioma model. The microvessel density (MVD) and apoptotic cells in a C6/LacZ rat glioma orthotopic model were determined by immunohistological staining with CD31 antibody and TUNEL kit, respectively.

The number of blood vessels stained with CD31 was decreased in all groups treated with TMZ compared with those of controls (Table I, Fig. 2B and D). The group of rats daily administered with $2 \mathrm{mg} / \mathrm{kg}$ TMZ showed $48 \%$ decrease $(\mathrm{P}<0.001)$ in MVD relative to control, which is significantly different compared with the other groups. These results demonstrated that the protracted treatment of $\mathrm{TMZ}$ with proper low dose was more effective on inhibition of tumor growth and angiogenesis than the relatively high dose of conventional consecutive TMZ chemotherapy for 5 days. C6 glioma in SD rats, which is TMZ chemoresistant in conventional chemotherapy, became sensitive to a frequent low-dose schedule.

The apoptotic cells determined by TUNEL assay were observed in rats treated with each dose of TMZ. While TUNEL-positive cells were rarely detected in control, TUNELstained cells were shown in all groups treated with TMZ (Table I, Fig. 2C and D). Moreover, in the group of rats metronomically administered $2 \mathrm{mg} / \mathrm{kg} \mathrm{TMZ}$, the number of 
Table II. Tumor volume and MVD in human U-87MG glioma xenograft model.

\begin{tabular}{lccccc}
\hline $\begin{array}{l}\text { Treatment } \\
\text { group }\end{array}$ & \multicolumn{2}{c}{ Tumor volume $\left(\mathrm{mm}^{3}\right)$} & & \multicolumn{2}{c}{ MVD (no.) } \\
\cline { 2 - 3 } \cline { 5 - 6 } & Median & Range & & Median & Range \\
\hline Control & 178.0 & $4.5-180.0$ & & 11 & $6-16$ \\
$2.5 \mathrm{mg} / \mathrm{kg} \mathrm{TMZ}$ & $21.6^{\mathrm{a}}$ & $0.8-136.8$ & & 11.5 & $6-16$ \\
for 5 days & & & & \\
$\begin{array}{l}1.25 \mathrm{mg} / \mathrm{kg} \mathrm{TMZ} \\
\text { for } 5 \mathrm{days}\end{array}$ & 80.1 & $0.0-123.7$ & & 12.5 & $8-22$ \\
$\begin{array}{l}0.5 \mathrm{mg} / \mathrm{kg} \\
\text { TMZ daily }\end{array}$ & 18.5 & $2.5-126.3$ & & $7^{\mathrm{b}-\mathrm{d}}$ & $1-14$ \\
$\begin{array}{l}0.25 \mathrm{mg} / \mathrm{kg} \\
\text { TMZ daily }\end{array}$ & 105.8 & $84.5-171.7$ & & $8^{\mathrm{b}, \mathrm{d}}$ & $2-15$ \\
\hline
\end{tabular}

U-87MG human glioma cells $\left(1 \times 10^{5}\right)$ were injected into the male $\mathrm{Balb} / \mathrm{c}-\mathrm{nu}$ mice brain. Two groups of mice were treated orally with 2.5 or $1.25 \mathrm{mg} / \mathrm{kg}$ TMZ for 5 days. The other two groups of mice were administered orally with 0.5 or $0.25 \mathrm{mg} / \mathrm{kg}$ TMZ for everyday. The control group of mice was treated by p.o. injection with $10 \%$ DMSO. No. is the number of positive staining cells. ${ }^{\text {a Smaller than in }}$ gliomas of control group animals $(\mathrm{P}<0.05)$. bower than in gliomas of control group animals $(\mathrm{P}<0.05)$. ${ }^{c}$ Lower than in gliomas of mouse group administered $2.5 \mathrm{mg} / \mathrm{kg} \mathrm{TMZ}(\mathrm{P}<0.05)$. ${ }^{\mathrm{d}}$ Lower than in gliomas of group animals treated with $1.25 \mathrm{mg} / \mathrm{kg}$ TMZ $(\mathrm{P}<0.001)$. apoptotic cells showed a 7-fold increase $(\mathrm{P}<0.05)$ compared with that in controls (Table I, Fig. 2C and D).

Metronomic treatment with TMZ inhibits angiogenesis in U-87MG human glioblastoma orthotopic xenograft model. We also examined the effect of TMZ on the tumor volume and MVD in a U-87MG human glioblastoma orthotopic xenograft model according to treatments for respective doses of TMZ (Table II, Fig. 3). Since U-87MG in the nude mouse brain is sensitive to conventional TMZ chemotherapy, we reduced and treated it conventionally with TMZ at one third of the dose having an optimal effect and with TMZ divided into an everyday schedule at the same dose as conventional chemotherapy. Although there is no significant difference between the conventional and metronomic dose in tumor volume in this model, the antiangiogenic effect is more prominent in the metronomic dose schedule (Table II, Fig. 3A and B). In detail, the number of vessels stained with CD31 in mouse groups treated with TMZ for 5 days showed the similarity compared with that of controls, while the number of CD31 staining blood vessels in mouse groups metronomically treated with TMZ for everyday were decreased by $64 \%(0.5 \mathrm{mg} / \mathrm{kg}$ TMZ daily, $\mathrm{P}<0.05$, calculated by each value of median) and $73 \%(0.25 \mathrm{mg} / \mathrm{kg}$ TMZ daily, $\mathrm{P}<0.05)$ compared with those of controls (Table II, Fig. 3B and C).

\section{Discussion}

In this study, the effect of metronomic treatment with TMZ, one of the most commonly used chemotherapy agents for
A

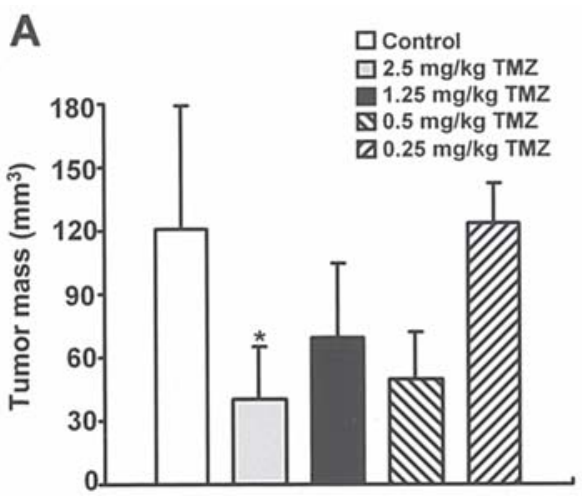

B

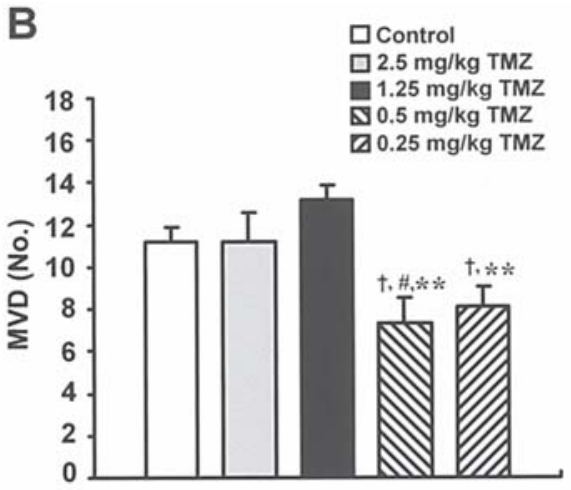

C

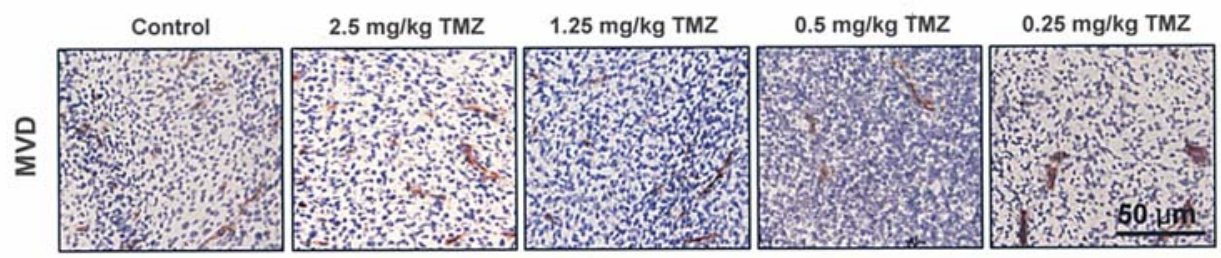

Figure 3. The effects of TMZ on a U-87MG human glioma xenograft model. Tumor volume (A) and MVD (B) are graphed respectively. Each value represents the mean $\pm \mathrm{SE}(\mathrm{n}=15)$. The values of mean in this figure are different from those of median in Table II. * Smaller than in gliomas of control group animals $(\mathrm{P}<0.05)$. tLower than in gliomas of control $(\mathrm{P}<0.05)$. "Lower than in gliomas of mouse group administered $2.5 \mathrm{mg} / \mathrm{kg} \mathrm{TMZ}(\mathrm{P}<0.05)$. ${ }^{* *} \mathrm{Lower}$ than in gliomas of group animals treated with $1.25 \mathrm{mg} / \mathrm{kg}$ TMZ $(\mathrm{P}<0.001)$. (C) Paraffin sections of the tumors were stained for endothelial cells using anti-CD31 antibody. 
malignant gliomas $(6,7)$, is investigated by cell proliferation assay in vitro and with rat and mouse orthotopic glioma model in vivo. Previous studies reported that antiangiogenic effects of different doses of TMZ are determined by the in vivo chorioallantoic membrane (CAM) assay, and HUVEC-based in vitro Matrigel, adhesion and proliferation assays (21). It was also demonstrated that TMZ inhibits tumor growth by inducing apoptosis in a three dimensional cell culture model of the glioma cell lines (22). In this report, we originally executed the metronomic chemotherapy of TMZ and optimized the antitumor activity of TMZ in orthotopic glioma models. We elucidate that frequent administration of TMZ at a low dose significantly inhibits the growth of tumor in relatively TMZresistant rat glioma. The mechanism of this antitumor activity is accompanied by the reduction of angiogenesis and the induction of apoptosis in TMZ-resistant and -sensitive animal models.

Clinically, concomitant radiation and TMZ chemotherapy shows a survival gain in glioblastoma patients. One of the reasons is that an everyday low-dose treatment schedule during radiation therapy for 6 weeks has a potent antiangiogenic or antivascular effect on glioblastoma, which has the most prominent endothelial proliferation compared with other cancers $(23,24)$.

Recently it was suggested that the endothelial cells in the vascular bed of tumor are more susceptible to chemotherapeutic agents than resting endothelium, because they have significantly higher proliferation rates than the normal endothelium in the rest of the body (25). In addition, before reaching tumor cells, these agents must meet microvascular endothelial cells in the tumor beds. Furthermore, endothelial cells are genetically stable, so they should be more susceptible to the apoptotic effects of chemotherapeutic agents than tumor cells (25). Therefore, the apoptotic effects of cytotoxic chemotherapy on proliferating vascular endothelial cells could contribute to the antitumor efficacy of chemotherapy.

Metronomic chemotherapy, continuous chemotherapeutic agent administration on a low-dose antiangiogenic schedule, exposes drugs to endothelial cells in the tumor beds and can induce apoptosis of endothelial cells preceding that of tumor cells. Various kinds of cytotoxic agents, according to the theory mentioned above, can be applied to diminish or to regress the tumor mass in experimental models and some patients (25-28). Similarly we hypothesized that the conventional chemotherapy of TMZ required a treatment-free interval to allow the recovery of tumor cell growth, implying that the presence of microvascular endothelial cells in the tumor bed involves resuming their proliferation and supporting tumor regrowth. Glioma-bearing animals conventionally treated with TMZ would have large tumors with a diminished response to $\mathrm{TMZ}$ which could acquire drug resistance. In contrast, when TMZ was administered more frequently and at lower doses without a prolonged treatment-free interval, tumors regressed without other toxicity in animals.

In conclusion, we demonstrate that frequent and continuous treatment with a low dose of TMZ showed high antitumor effects through, at least in part, its angiogenic and pro-apoptotic activity. Therefore, it should be strongly stressed that low-dose TMZ treatment frequently becomes a potential candidate as chemotherapy for malignant gliomas.

\section{Acknowledgements}

This study was supported by grants from Samsung Biomedical Research Institute (C-A4-208-2; D.-H. N.), from IN-SUNG Foundation for Medical Research (C-A4-826-1; J.-S. K. and C-A6-804-1; D.-H. N.) and from the Korea Health 21 R\&D Project, Ministry of Health and Welfare, Republic of Korea (Project No. 0405-B002-0205-0001). We are grateful for the support of Yuhan Corp. and to Dr Jin Hye Seo for critically reviewing the manuscript.

\section{References}

1. Curran WJ Jr, Scott CB, Horton J, Nelson JS, Weinstein AS, Fischbach AJ, Chang CH, Rotman M, Asbell SO, Krisch RE and Nelson DF: Recursive partitioning analysis of prognostic factors in three Radiation Therapy Oncology Group malignant glioma trials. J Natl Cancer Inst 85: 704-710, 1993.

2. Conrad CA, Milosavljevic VP and Yung WK: Advances in chemotherapy for brain tumors. Neurol Clin 13: 795-812, 1995.

3. Newlands ES, Stevens MF, Wedge SR, Wheelhouse RT and Brock C: Temozolomide: a review of its discovery, chemical properties, pre-clinical development and clinical trials. Cancer Treat Rev 23: 35-61, 1997.

4. Friedman HS, Kerby $\mathrm{T}$ and Calvert H: Temozolomide and treatment of malignant glioma. Clin Cancer Res 6: 2585-2597, 2000.

5. Yung WK: Temozolomide in malignant gliomas. Semin Oncol 27: 27-34, 2000.

6. Nagasubramanian R and Dolan ME: Temozolomide: realizing the promise and potential. Curr Opin Oncol 15: 412-418, 2003.

7. Chang SM, Lamborn KR, Malec M, Larson D, Wara W, Sneed P, Rabbitt J, Page M, Nicholas MK and Prados MD: Phase II study of temozolomide and thalidomide with radiation therapy for newly diagnosed glioblastoma multiforme. Int J Radiat Oncol Biol Phys 60: 353-357, 2004

8. Ravizza R, Cereda E, Monti E and Gariboldi MB: The piperidine nitroxide Tempol potentiates the cytotoxic effects of temozolomide in human glioblastoma cells. Int J Oncol 25: 1817-1822, 2004.

9. Houghton PJ, Stewart CF, Cheshire PJ, Richmond LB, Kirstein MN, Poquette CA, Tan M, Friedman HS and Brent TP: Antitumor activity of temozolomide combined with irinotecan is partly independent of O6-methylguanine-DNA methyltransferase and mismatch repair phenotypes in xenograft models. Clin Cancer Res 6: 4110-4118, 2000.

10. Plowman J, Waud WR, Koutsoukos AD, Rubinstein LV, Moore TD and Grever MR: Preclinical antitumor activity of temozolomide in mice: efficacy against human brain tumor xenografts and synergism with 1,3-bis(2-chloroethyl)-1-nitrosourea. Cancer Res 54: 3793-3799, 1994.

11. Wedge SR, Porteous JK, Glaser MG, Marcus K and Newlands ES: In vitro evaluation of temozolomide combined with $\mathrm{X}$-irradiation. Anticancer Drugs 8: 92-97, 1997.

12. Stevens MF, Hickman JA, Langdon SP, Chubb D, Vickers L, Stone R, Baig G, Goddard C, Gibson NW, Slack JA, Newton C, Lunt E, Fizames C and Lavelle F: Antitumor activity and pharmacokinetics in mice of 8-carbamoyl-3-methyl-imidazo [5,1-d]-1,2,3,5-tetrazin-4(3H)-one (CCRG 81045; M\&B 39831), a novel drug with potential as an alternative to dacarbazine. Cancer Res 47: 5846-5852, 1987.

13. Eberhard A, Kahlert S, Goede V, Hemmerlein B, Plate KH and Augustin HG: Heterogeneity of angiogenesis and blood vessel maturation in human tumors: implications for antiangiogenic tumor therapies. Cancer Res 60: 1388-1393, 2000.

14. Klement G, Baruchel S, Rak J, Man S, Clark K, Hicklin DJ, Bohlen P and Kerbel RS: Continuous low-dose therapy with vinblastine and VEGF receptor-2 antibody induces sustained tumor regression without overt toxicity. J Clin Invest 105: R15-R24, 2000.

15. Bocci G, Nicolaou KC and Kerbel RS: Protracted low-dose effects on human endothelial cell proliferation and survival in vitro reveal a selective antiangiogenic window for various chemotherapeutic drugs. Cancer Res 62: 6938-6943, 2002.

16. Gasparini G: Metronomic scheduling: the future of chemotherapy. Lancet Oncol 2: 733-740, 2001. 
17. Kerbel RS and Kamen BA: The anti-angiogenic basis of metronomic chemotherapy. Nat Rev Cancer 4: 423-436, 2004.

18. Omidi Y, Campbell L, Barar J, Connell D, Akhtar S and Gumbleton M: Evaluation of the immortalised mouse brain capillary endothelial cell line, b.End3, as an in vitro blood-brain barrier model for drug uptake and transport studies. Brain Res 990: 95-112, 2003.

19. Lal S, Lacroix M, Tofilon P, Fuller GN, Sawaya R and Lang FF: An implantable guide-screw system for brain tumor studies in small animals. J Neurosurg 92: 326-333, 2000.

20. Nam DH, Park K, Park C, Im YH, Kim MH, Lee S, Hong SC, Shin HJ, Kim JH, Eoh W and McDonnell TJ: Intracranial inhibition of glioma cell growth by cyclooxygenase-2 inhibitor celecoxib. Oncol Rep 11: 263-268, 2004.

21. Kurzen H, Schmitt S, Naher H and Mohler T: Inhibition of angiogenesis by non-toxic doses of temozolomide. Anticancer Drugs 14: 515-522, 2003.

22. Gunther W, Pawlak E, Damasceno R, Arnold H and Terzis AJ: Temozolomide induces apoptosis and senescence in glioma cells cultured as multicellular spheroids. Br J Cancer 88: 463-469, 2003.
23. Stupp R, Dietrich PY, Ostermann Kraljevic S, Pica A, Maillard I, Maeder P, Meuli R, Janzer R, Pizzolato G, Miralbell R, Porchet F, Regli L, De Tribolet N, Mirimanoff RO and Leyvraz S: Promising survival for patients with newly diagnosed glioblastoma multiforme treated with concomitant radiation plus temozolomide followed by adjuvant temozolomide. J Clin Oncol 20: 1375-1382, 2002.

24. Stupp R, Mason WP, van den Bent MJ, et al: Radiotherapy plus concomitant and adjuvant temozolomide for glioblastoma. $\mathrm{N}$ Engl J Med 352: 987-996, 2005.

25. Folkman J: Angiogenesis and apoptosis. Semin Cancer Biol 13: 159-167, 2003.

26. Hansen RM, Ryan L, Anderson T, Krzywda B, Quebbeman E, Benson A III, Haller DG and Tormey DC: Phase III study of bolus versus infusion fluorouracil with or without cisplatin in advanced colorectal cancer. J Natl Cancer Inst 88: 668-674, 1996.

27. Neskovic-Konstantinovic ZB, Bosnjak SM, Radulovic SS and Mitrovic LB: Daily oral etoposide in metastatic breast cancer. Anticancer Drugs 7: 543-547, 1996.

28. Browder T, Butterfield CE, Kraling BM, Shi B, Marshall B, O'Reilly MS and Folkman J: Antiangiogenic scheduling of chemotherapy improves efficacy against experimental drugresistant cancer. Cancer Res 60: 1878-1886, 2000. 